\title{
Primary Cutaneous B-Cell/T-Cell (Non- MF/SS) Lymphoma Distant Metastasis TNM Finding v8
}

National Cancer Institute

\section{Source}

National Cancer Institute. Primary Cutaneous B-Cell/T-Cell (Non-MF/SS) Lymphoma

Distant Metastasis TNM Finding v8. NCI Thesaurus. Code C141373.

A finding about one or more characteristics of primary cutaneous B-cell/T-cell (nonMF/SS) lymphoma, following the rules of the TNM AJCC v8 classification system as they pertain to distant metastases. (from AJCC 8th Ed.) 